\title{
Uranium Isotope Evidence for Temporary Ocean Oxygenation in the Aftermath of the Sturtian Snowball Earth
}

\section{Citation}

Lau, Kimberly V., Francis A. Macdonald, Kate Maher, and Jonathan L. Payne. 2017. Uranium Isotope Evidence for Temporary Ocean Oxygenation in the Aftermath of the Sturtian Snowball Earth. Earth and Planetary Science Letters 458: 282-292.

\section{Permanent link}

http://nrs.harvard.edu/urn-3:HUL.InstRepos:41291501

\section{Terms of Use}

This article was downloaded from Harvard University's DASH repository, WARNING: This file should NOT have been available for downloading from Harvard University's DASH repository.

\section{Share Your Story}

The Harvard community has made this article openly available.

Please share how this access benefits you. Submit a story.

\section{Accessibility}




\title{
Uranium isotope evidence for temporary ocean oxygenation in the aftermath of the Sturtian Snowball Earth
}

\author{
Kimberly V. Lau ${ }^{\mathrm{a}, *}$, Francis A. Macdonald ${ }^{\mathrm{b}}$, Kate Maher ${ }^{\mathrm{a}}$, Jonathan L. Payne ${ }^{\mathrm{a}}$ \\ a Department of Geological Sciences, Stanford University, 450 Serra Mall, Bldg. 320, Stanford, CA 94305, USA \\ b Department of Earth and Planetary Sciences, Harvard University, 20 Oxford Street, Cambridge, MA 02138, USA
}

\section{A R T I C L E I N F O}

\section{Article history:}

Received 23 May 2016

Received in revised form 19 October 2016

Accepted 21 October 2016

Available online 14 November 2016

Editor: D. Vance

\section{Keywords:}

Neoproterozoic

paleoredox

uranium isotopes

Cryogenian

Snowball Earth glaciation

\begin{abstract}
A B S T R A C T
The appearance and radiation of animals are commonly attributed to Neoproterozoic oceanic oxygenation, yet independent geochemical evidence for such an event remains equivocal. Strata deposited between the Sturtian and Marinoan Snowball Earth glaciations (660 to $640 \mathrm{Ma}$ ) contain the earliest animal biomarkers and possible body fossils. To quantify the extent of seafloor oxygenation during this critical interval, we present uranium isotope ratios $\left({ }^{238} \mathrm{U} /{ }^{235} \mathrm{U}\right.$ denoted as $\left.\delta^{238} \mathrm{U}\right)$ from limestone of the Taishir Formation in Mongolia through two stratigraphic sections that are separated by $\sim 75 \mathrm{~km}$ within the same depositional basin. Above the Sturtian glacial deposits, through $\sim 150 \mathrm{~m}$ of stratigraphy, $\delta^{238} \mathrm{U}$ compositions have a mean value of $-0.47 \%$. This interval is followed by a $\sim 0.3 \%$ decrease in $\delta^{238} \mathrm{U}$, coincident with the Taishir negative carbon isotope excursion. Thereafter, $\delta^{238} \mathrm{U}$ values remain relatively low until the erosional unconformity at the base of the Marinoan glacial deposits. Using a box model, we show that the best explanation for the higher $\delta^{238} \mathrm{U}$ values of the post-Sturtian limestones is extensive-but temporary-oxygenation of the seafloor, and is inconsistent with a scenario involving only increased delivery of uranium to the oceans due to post-Snowball weathering. The decline in $\delta^{238} \mathrm{U}$ in overlying strata, coincident with the Taishir negative $\delta^{13} \mathrm{C}$ excursion, indicates a subsequent decrease in seafloor oxygenation. The $\mathrm{U}$ isotopic data, combined with modeling results, challenge the notion of a simple, unidirectional oxygenation of Neoproterozoic oceans.
\end{abstract}

(c) 2016 Elsevier B.V. All rights reserved.

\section{Introduction}

The oxygenation of the Earth's atmosphere and oceans is hypothesized to have occurred in two steps: the Great Oxidation Event (GOE, ca. $2.2 \mathrm{Ga}$ ) and the Neoproterozoic Oxidation Event (NOE, ca. 0.8 to $0.5 \mathrm{Ga}$ ) (Lenton et al., 2014; Lyons et al., 2014; Och and Shields-Zhou, 2012). Unlike the GOE, which is demarcated by the disappearance of sulfur mass independent fractionation, the timing and magnitude of the NOE remains poorly resolved (Lyons et al., 2014; Och and Shields-Zhou, 2012). In particular, previous studies used proxies, such as Fe speciation and metal enrichments, that are influenced by local redox conditions (e.g., Canfield et al., 2008; Li et al., 2012). Compilation of Fe speciation data across multiple basins suggests a heterogeneous Neoproterozoic seafloor, but global average redox conditions are difficult to quantify due to uneven spatial coverage and coarse age-binning of data (Sperling et al., 2015). Here, we provide high-resolution constraints on the NOE

\footnotetext{
* Corresponding author.

E-mail address: kvlau@stanford.edu (K.V. Lau).
}

with uranium isotopic ratios $\left({ }^{238} \mathrm{U} /{ }^{235} \mathrm{U}\right.$, expressed as $\left.\delta^{238} \mathrm{U}\right)$ in carbonate rocks.

Uranium has a long residence time in the ocean ( $\sim 500 \mathrm{kyr})$ relative to ocean mixing time $(\sim 1 \mathrm{kyr})$ (Andersen et al., 2016 and the references therein), meaning that local measurements have the potential to be globally representative. Uranium occurs in two redox states in natural waters: $\mathrm{U}(\mathrm{VI})$ and $\mathrm{U}(\mathrm{IV})$. Under oxygenated conditions, $\mathrm{U}(\mathrm{VI})$ forms a suite of aqueous calcium and carbonate complexes. Within anoxic sediments, $\mathrm{U}(\mathrm{VI})$ is reduced to U(IV), which is insoluble (e.g., Andersen et al., 2014). Moreover, ${ }^{238} \mathrm{U}$ is preferentially reduced relative to ${ }^{235} \mathrm{U}$, leaving the residual aqueous $\mathrm{U}(\mathrm{VI})$ with a lower $\delta^{238} \mathrm{U}$ value compared to reduced uranium in sediments (Stirling et al., 2007; Weyer et al., 2008). Therefore, if the extent of seafloor anoxia increases globally, the residual aqueous $\mathrm{U}(\mathrm{VI})$ in seawater-which is subsequently incorporated into carbonate sediments-should decrease in both concentration ([U]) and $\delta^{238} \mathrm{U}$. This approach has been used to constrain the extent of anoxia associated with the end-Permian mass extinction (Brennecka et al., 2011; Lau et al., 2016) and the Cambrian SPICE (Dahl et al., 2014). The global nature of the carbonate $\delta^{238} \mathrm{U}$ signal is supported by a negative shift of $\sim-0.4 \%$ spanning the Permian-Triassic boundary in multiple 
NEOPROTEROZOIC ERA

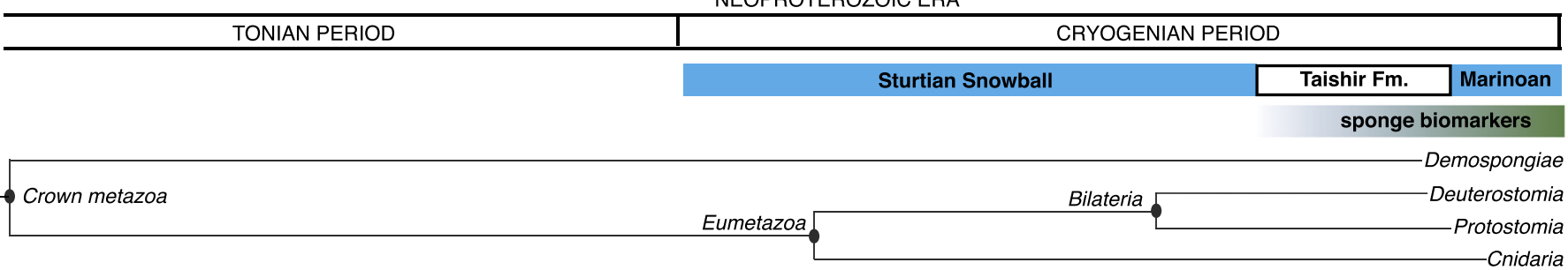

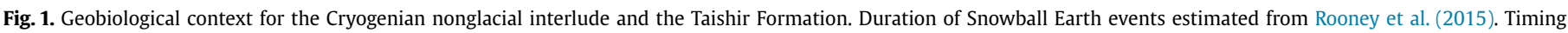
of sponge biomarkers estimated from Love et al. (2009). Molecular clock estimates from Erwin et al. (2011).

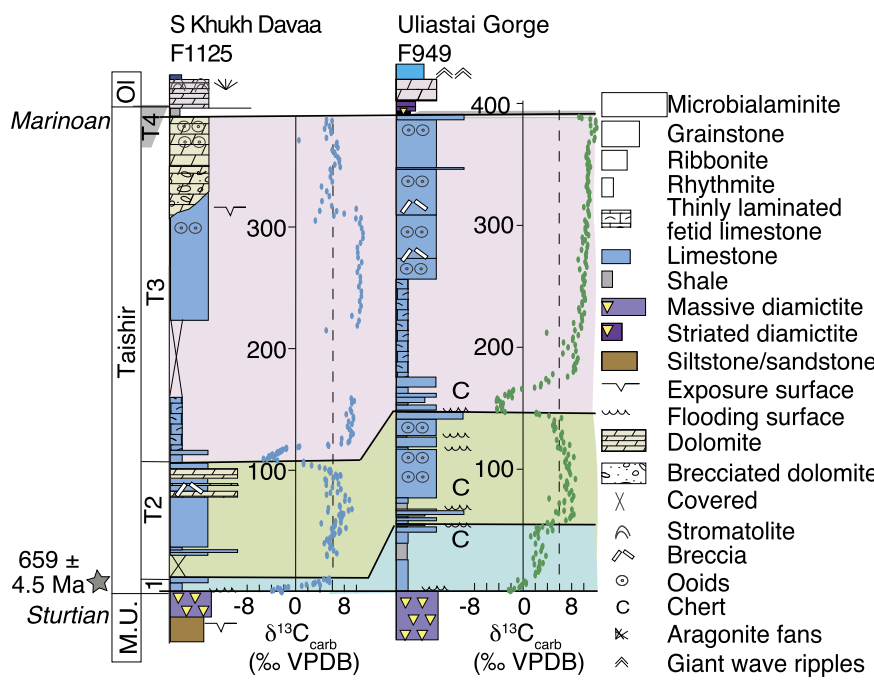

Fig. 2. Stratigraphic framework and stratigraphic columns of the two studied sections, modified from Bold et al. (2016). M.U. is the Maikhan Uul Formation. The $\delta^{13} C_{\text {carb }}$ data are from Bold et al. (2016) (F1125) and Johnston et al. (2012) (F949). Gray star marks the Re-Os geochronological date from Rooney et al. (2015).

stratigraphic sections across geographically distinct areas (Lau et al., 2016).

The Neoproterozoic is divided into the Tonian (1000-720 Ma), Cryogenian (720-635 Ma), and Ediacaran (635-541 Ma) periods (Fig. 1). The Cryogenian is bookended by two low-latitude glaciations, or "Snowball Earth" events (Hoffman et al., 1998): the Sturtian (ca. 717-660 Ma) and Marinoan (beginning by 650-640 Ma and ending at ca. $635 \mathrm{Ma}$ ) glaciations (Rooney et al., 2015). We focus our study of the NOE on the intervening Cryogenian nonglacial interlude because this interval encompasses the transition from diploblastic to triploblastic animal phyla according to molecular clock estimates (Erwin et al., 2011) and hosts the oldest animal molecular fossils (Love et al., 2009) as well as possible body fossils (Maloof et al., 2010). Although the relationship between animal evolution and ocean oxygenation is uncertain (e.g., Lenton et al., 2014), insights into the role of changing redox conditions on the rise of early animals requires high-resolution, global constraints on the changing availability of oxygen in seawater during this critical interval.

In addition to the first appearance of metazoans, Cryogenian strata contain large negative carbonate-carbon isotope $\left(\delta^{13} \mathrm{C}_{\mathrm{carb}}\right)$ excursions from a high background (Fig. 2) (Johnston et al., 2012). Within the Cryogenian nonglacial interlude, the $\delta^{13} \mathrm{C}_{\text {carb }}$ record exhibits a basal excursion to $-4 \%$ in the Sturtian cap carbonate, followed by a rise to enriched values of $+8 \%$, a second negative $\delta^{13} \mathrm{C}_{\text {carb }}$ excursion to $-7 \%$, referred to as the Taishir excursion (Macdonald et al., 2009), followed by a second rise to $+10 \%$, with the organic carbon $\left(\delta^{13} C_{\text {org }}\right)$ record mirroring these trends but with an offset of $-25 \%$ (Johnston et al., 2012). Because variations in $\delta^{13} \mathrm{C}_{\text {carb }}$ are canonically interpreted as changes in the organic carbon burial flux relative to total carbon burial, the observed isotopic shifts imply extreme changes in the redox state of the ocean (Bristow and Kennedy, 2008)-but changes in oxygenation associated with these excursions have yet to be identified.

\section{Materials and methods}

\subsection{Geologic setting}

We analyzed limestone samples collected from two stratigraphic sections on the Zavkhan Terrane, southwest Mongolia, spanning the Cryogenian nonglacial interlude (Fig. S1) (Bold et al., 2016; Macdonald et al., 2009). This region has a welldeveloped stratigraphic and geochemical framework (Bold et al., 2016; Johnston et al., 2012; Macdonald et al., 2009) and hosts a rich assemblage of eukaryotic microfossils (Cohen and Macdonald, 2015 and the references therein). These strata were deposited on a marine carbonate ramp (described in the Supplementary Materials). The stratigraphy is divided into three members: the basal T1 member contains the post-Sturtian cap carbonate, and the overlying T2 and T3 members are separated by the Taishir $\delta^{13} \mathrm{C}_{\mathrm{carb}}$ excursion (Bold et al., 2016). We analyzed 26 samples from the more proximal section, Uliastai Gorge (F949), that span the entire T1 through T3 interval, and 34 samples from the more distal section, South Khukh Davaa (F1125), primarily focusing on the T1 and T2 members. The age model for the Cryogenian nonglacial interlude is bracketed below by Re-Os dates from Sturtian cap carbonates in Mongolia of $659.0 \pm 4.5$ Ma (Rooney et al., 2015), and above by Marinoan glacial deposits. Estimates for the duration of this interval and the Taishir Formation range from 8.6 to $19.4 \mathrm{Myr}$ (Rooney et al., 2015).

\subsection{Carbon and oxygen isotopic analyses}

Carbon and oxygen isotopic data from F949 are previously published in Johnston et al. (2012), and from F1125 in Bold et al. (2016). Additional carbon and oxygen isotope analyses for 33 samples from F1125 were performed in the Stable Isotope Biogeochemistry Laboratory at Stanford University using a Finnegan MAT252 mass spectrometer coupled to a Kiel III carbonate device. Between 50 and $100 \mu \mathrm{g}$ of limestone powder were reacted in phosphoric acid $\left(\mathrm{H}_{3} \mathrm{PO}_{4}\right)$ at $70^{\circ} \mathrm{C}$ for $600 \mathrm{~s}$. All $\delta^{13} \mathrm{C}$ and $\delta^{18} \mathrm{O}$ values are reported relative to V-PDB (Vienna Pee Dee Belemnite).

\subsection{Concentration measurements}

Sample powders were dissolved using $1 \mathrm{~N}$ hydrochloric acid $(\mathrm{HCl})$; insoluble residues were removed via centrifugation. Major elemental concentrations ( $\mathrm{Ca}, \mathrm{Mg}, \mathrm{Al}, \mathrm{Sr}, \mathrm{Mn}, \mathrm{Fe}$ ) were measured on a Thermo Scientific ICAP 6300 Duo View ICP-OES in the Environmental Measurements 1 Laboratory (EM-1) at Stanford Univer- 

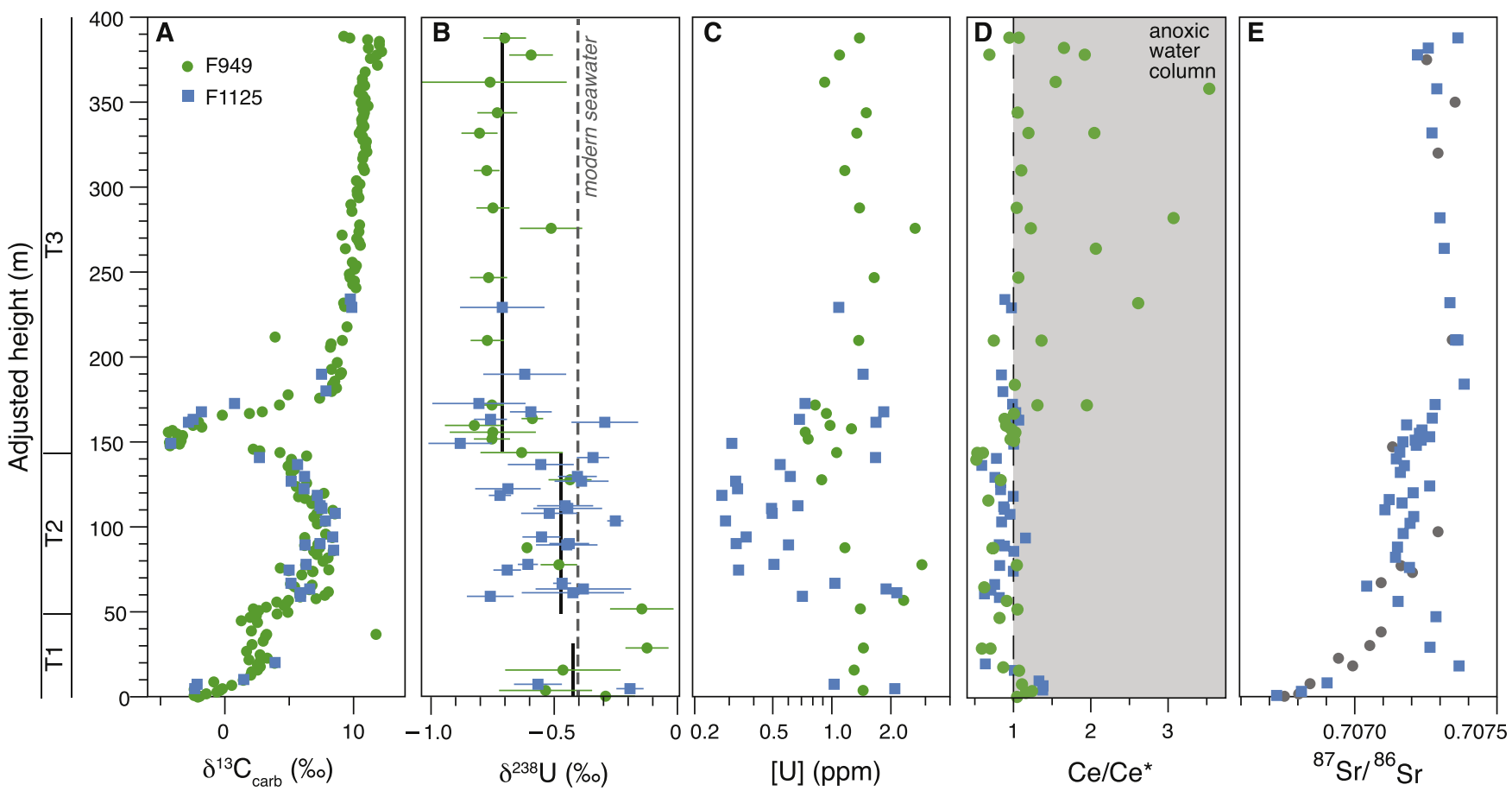

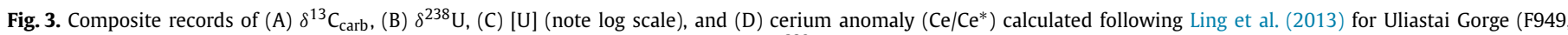

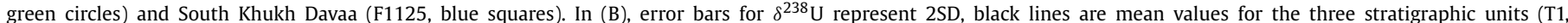

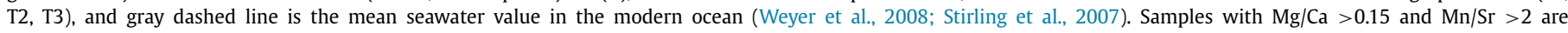

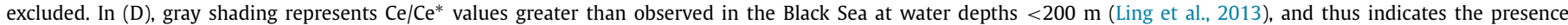

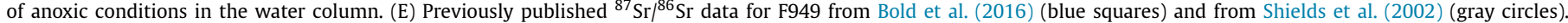

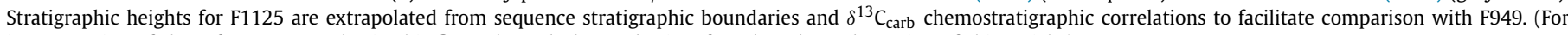
interpretation of the references to color in this figure legend, the reader is referred to the web version of this article.)

sity. Minor elemental concentrations ( $U$ and rare earth elements) were measured on a Thermo X-series 2 ICP-MS in EM-1.

\subsection{Uranium isotopic analysis}

Sample preparation and analytical procedures follow those of Lau et al. (2016), with additional details in the Supplementary Materials. At least $4 \mathrm{~g}$ of homogenized bulk carbonate powder was digested using $0.25 \mathrm{~N}$ Optima ${ }^{\mathrm{TM}} \mathrm{HCl}$. Uranium was purified by a two-step ion exchange chromatography procedure using UTEVA resin. The isotopic composition of the resulting solutions was measured in the ICP-MS/TIMS Facility at Stanford University on a $\mathrm{Nu}$ Plasma HR MC-ICP-MS. The ${ }^{238} \mathrm{U} /{ }^{235} \mathrm{U}$ ratios are reported relative to CRM-145 in standard delta notation. Isotope ratio errors were propagated by summation in quadrature and reported as standard deviations (2SD calculated from the reproducibility of at least three replicate measurements of the same sample solution), with a mean value of $0.12 \%$. Internal precision (2SE) of measurements was typically $0.07 \%$. Additionally, we processed five samples in replicate from powder to evaluate external reproducibility and show general agreement among the duplicates (Table S1). For three of these samples, the duplicates differed by $<0.04 \%$, whereas the $0.25 \% 0$ difference for F1125-57 fell within the internal measurement error. The reproducibility (2SD) of one sample (F1125-75.6) was poor, at $>1 \%$. Because the internal error for one duplicate for this sample was $0.75 \%$, this is likely an outlier.

\section{Results}

\subsection{Uranium concentrations and isotope compositions}

We generated a composite record for $\delta^{238} U$ using sequence and carbon isotope chemostratigraphy for correlation (Fig. 3). To aid in visual comparison of the data and model, stratigraphic heights for F1125 were interpolated to be comparable to the measured heights for F949 by assuming linear sedimentation rates between tie points. We screened our data by considering only those samples where supplemental geochemical data suggest no significant alteration $(\mathrm{Mg} / \mathrm{Ca}<0.15, \mathrm{Mn} / \mathrm{Sr}<2$; Brand and Veizer, 1980) and exclude five samples meeting this criteria (Table S1). In the basal member, $\mathrm{T} 1, \delta^{238} \mathrm{U}$ values have a mean of $-0.41 \pm 0.33 \%$ (2SD) whereas [U] have a mean of $1.4 \pm 0.9 \mathrm{ppm}$. In the T2 member, both $\delta^{238} \mathrm{U}$ and [U] values decrease slightly to mean values of $-0.48 \pm 0.33 \%$ and $0.7 \pm 1.4 \mathrm{ppm}$, respectively. In the T3 member, $\delta^{238} \mathrm{U}$ values decrease to a mean value of $-0.70 \% 0 \pm 0.25$, whereas [U] values have a mean of $1.2 \pm 1.1 \mathrm{ppm}$. Thus, variance in $\delta^{238} \mathrm{U}$ is greatest in $\mathrm{T} 1$ and $\mathrm{T} 2$, and lowest in $\mathrm{T} 3$.

\subsection{Rare earth element data}

Rare earth element (REE) anomalies are calculated following Ling et al. (2013) (Fig. 3). Here we present cerium (Ce) anomaly values $\left(\mathrm{Ce} / \mathrm{Ce}^{*}=[\mathrm{Ce}]_{\mathrm{SN}} /\left([\mathrm{Pr}]_{\mathrm{SN}}^{2} /[\mathrm{Nd}]_{\mathrm{SN}}\right)\right.$, where SN indicates concentrations normalized to Post-Archean Australian Shale values). In the composite section, $\mathrm{Ce} / \mathrm{Ce}^{*}$ values are generally greater than or near 1 from 0 to $50 \mathrm{~m}$, less than 1 from 20 to $150 \mathrm{~m}$, and greater than or near 1 for the remainder of the section. Values of $\mathrm{Ce} / \mathrm{Ce}^{*}$ are at a minimum from 30 to $60 \mathrm{~m}$ and from 120 to $140 \mathrm{~m}$.

\subsection{Statistical analyses for diagenetic indicators}

After initial diagenetic screening (section 3.1), we evaluated the relationships between the $\delta^{238} \mathrm{U}$ and [U] data and geochemical indicators of diagenetic alteration $\left(\delta^{18} \mathrm{O}, \mathrm{Mn} / \mathrm{Sr}\right.$, total organic carbon (TOC), and [Fe]), recrystallization from aragonite $(\mathrm{Sr} / \mathrm{Ca})$ or to dolomite $(\mathrm{Mg} / \mathrm{Ca})$, and contributions from detrital components ( $\mathrm{Al}$ ) by calculating Spearman's rank correlation coefficients $(\rho)$ (Table S2, Fig. 4). Only [Al] is significantly correlated with $\delta^{238} \mathrm{U}$ when 


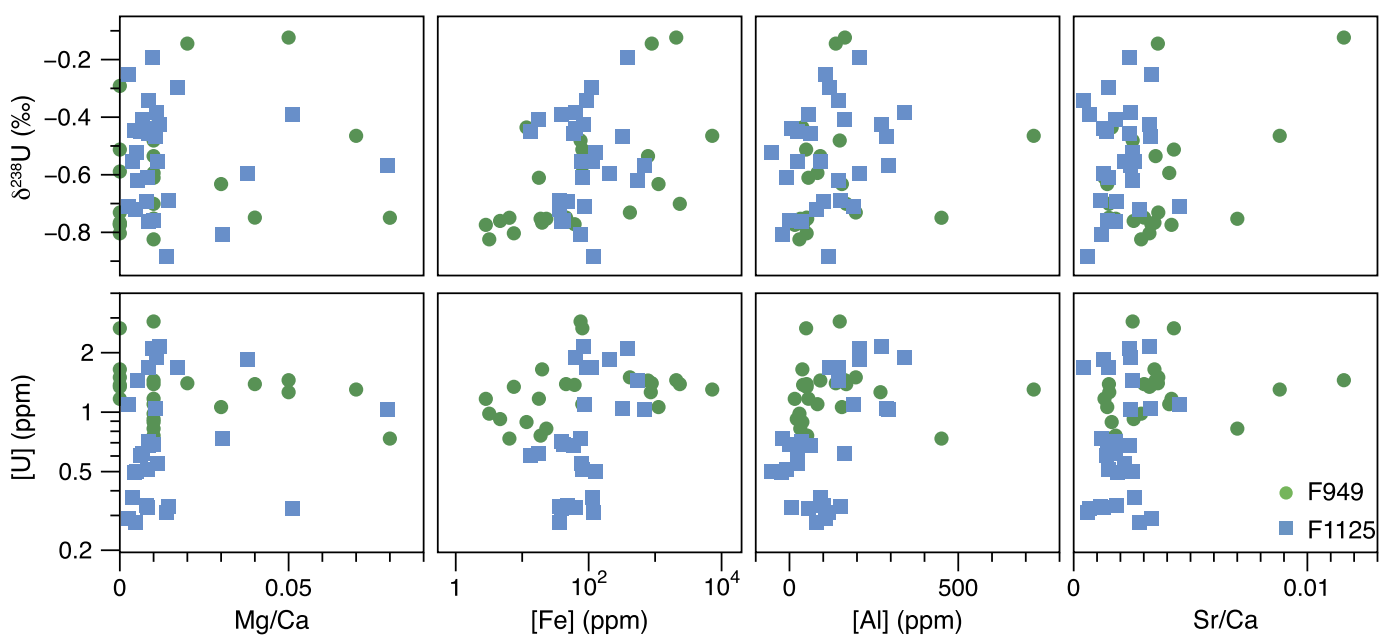

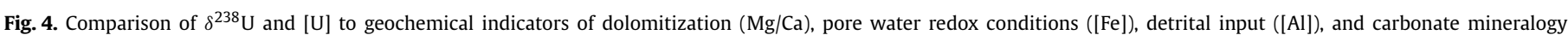

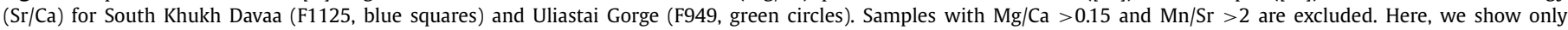

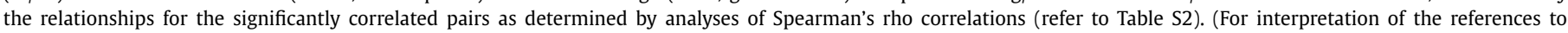
color in this figure legend, the reader is referred to the web version of this article.)

Table 1

ANOVA statistical results comparing $\delta^{238} \mathrm{U}$ and [U] between time intervals. Only data where $\mathrm{Mg} / \mathrm{Ca}<0.15$ and $\mathrm{Mn} / \mathrm{Sr}<2$ are included. Significant comparisons are bolded.

\begin{tabular}{|c|c|c|c|c|c|c|c|c|c|}
\hline & \multicolumn{2}{|l|}{ ANOVA } & \multicolumn{7}{|c|}{ Dunnett's modified Tukey-Kramer Post-Hoc Test } \\
\hline & \multirow{2}{*}{$\begin{array}{l}\delta^{238} \mathrm{U} \\
p \text {-value }\end{array}$} & \multirow{2}{*}{$\begin{array}{l}{[\mathrm{U}]} \\
p \text {-value }\end{array}$} & \multirow{2}{*}{$\begin{array}{l}\text { Pair-wise } \\
\text { comparison }\end{array}$} & \multicolumn{3}{|c|}{$\delta^{238} \mathrm{U}$} & \multicolumn{3}{|l|}{$[\mathrm{U}]$} \\
\hline & & & & Mean diff. & Lower $\mathrm{CI}$ & Upper CI & Mean diff. & Lower CI & Upper CI \\
\hline All data & $<0.001$ & 0.004 & $\begin{array}{l}\mathrm{T} 1-\mathrm{T} 2 \\
\mathrm{~T} 1-\mathrm{T} 3 \\
\mathrm{~T} 2-\mathrm{T} 3\end{array}$ & $\begin{array}{l}-0.072 \\
-\mathbf{0 . 2 9 4} \\
-\mathbf{0 . 2 2 2}\end{array}$ & $\begin{array}{l}-0.247 \\
-\mathbf{0 . 4 6 9} \\
-\mathbf{0 . 3 2 5}\end{array}$ & $\begin{array}{l}0.101 \\
-\mathbf{0 . 1 1 9} \\
-\mathbf{0 . 1 1 9}\end{array}$ & $\begin{array}{l}-0.309 \\
-0.088 \\
\mathbf{0 . 2 2 0}\end{array}$ & $\begin{array}{l}-0.632 \\
-0.413 \\
\mathbf{0 . 0 5 0}\end{array}$ & $\begin{array}{l}0.014 \\
0.236 \\
\mathbf{0 . 3 9 0}\end{array}$ \\
\hline F949 & $<0.001$ & 0.702 & $\begin{array}{l}\mathrm{T} 1-\mathrm{T} 2 \\
\mathrm{~T} 1-\mathrm{T} 3 \\
\mathrm{~T} 2-\mathrm{T} 3\end{array}$ & $\begin{array}{l}0.026 \\
-\mathbf{0 . 3 0 1} \\
-\mathbf{0 . 3 2 7}\end{array}$ & $\begin{array}{l}-0.217 \\
-\mathbf{0 . 4 8 8} \\
\mathbf{- 0 . 4 9 4}\end{array}$ & $\begin{array}{l}0.269 \\
-\mathbf{0 . 0 8 3} \\
\mathbf{- 0 . 1 6 0}\end{array}$ & $\begin{array}{l}\text { NA } \\
\text { NA } \\
\text { NA }\end{array}$ & $\begin{array}{l}\text { NA } \\
\text { NA } \\
\text { NA }\end{array}$ & $\begin{array}{l}\text { NA } \\
\text { NA } \\
\text { NA }\end{array}$ \\
\hline F1125 & 0.023 & 0.017 & $\begin{array}{l}\text { T1-T2 } \\
\text { T1-T3 } \\
\text { T2-T3 }\end{array}$ & $\begin{array}{l}-0.127 \\
-0.282 \\
\mathbf{- 0 . 1 5 5}\end{array}$ & $\begin{array}{l}-0.410 \\
-0.580 \\
\mathbf{- 0 . 3 0 9}\end{array}$ & $\begin{array}{l}0.155 \\
0.016 \\
\mathbf{- 0 . 0 0 1}\end{array}$ & $\begin{array}{l}-0.412 \\
-0.130 \\
\mathbf{0 . 2 8 2}\end{array}$ & $\begin{array}{l}-0.906 \\
-0.651 \\
\mathbf{0 . 0 1 4}\end{array}$ & $\begin{array}{l}0.083 \\
0.391 \\
\mathbf{0 . 5 4 9}\end{array}$ \\
\hline
\end{tabular}

data from the two measured sections are combined $(\rho=0.29$, $p$-value $=0.03)$. When the two sections are analyzed separately, however, this correlation is confined to the F949 section $(\rho=0.61$, $p$-value $<0.01)$. The $\delta^{238} \mathrm{U}$ values are also positively correlated with $\mathrm{Mg} / \mathrm{Ca}$ and $[\mathrm{Fe}]$ in the F949 section ( $\rho=0.55$ and 0.71 ; $p$-value $=0.01$ and $<0.001$, respectively). In comparison, the combined [U] data are correlated with $\mathrm{Sr} / \mathrm{Ca}$ ratios, [Fe], and [Al]. Of these, only the relationship with [Fe] remains significant when analyzed for the individual sections. The associated correlation coefficients are generally $<0.5$, indicating that these parameters cannot fully explain the variation in [U].

\subsection{Statistical analyses of differences between stratigraphic sections and among time intervals}

To further explore the influence of local influences, we use t-tests to compare between sections for each time interval. Although there are significant differences between F949 and F1125 for the [U] data from the T2 member (mean difference $=0.9 \mathrm{ppm}$, $p$-value $=0.004)$, there is no significant difference between either $\delta^{238} \mathrm{U}$ or [U] for the T1 and T3 members. The difference in [U] between the sections in the T2 member may result from the stratigraphic distribution of samples rather than differences among coeval samples. For example, samples from F949 have relatively high concentrations at $\sim 30 \mathrm{~m}$ to $50 \mathrm{~m}$, but there are no comparable F1125 samples from that stratigraphic interval for direct comparison. Similarly, [U] are relatively low from $100 \mathrm{~m}$ to $125 \mathrm{~m}$, but this interval is primarily composed of samples from F1125.
Although there are no large or consistent differences among sections, there are significant temporal differences within each section and when the data are combined. ANOVA results indicate that $\delta^{238} \mathrm{U}$ values for $\mathrm{T} 1$ and $\mathrm{T} 2$ are statistically indistinguishable, but are distinct from T3 (Table 1). Additionally, comparisons to modern seawater $(-0.41 \pm 0.14 \%$; Andersen et al., 2014; Stirling et al., 2007; Tissot and Dauphas, 2015; Weyer et al., 2008) indicate that mean $\delta^{238} \mathrm{U}$ values for T1 are indistinguishable from modern values (Student's t-test $p$-value $=0.87$, mean difference $=0.01 \%$ ) , whereas values for T2 are marginally different ( $p$-value $=0.02$, mean difference $=0.09 \%$ ) , and significantly different for T3 $(p$-value $\leq 0.001$, mean difference $=0.31 \%$ ). Because continental crust has a $\delta^{238} \mathrm{U}$ value more positive than seawater $(\sim-0.3 \pm 0.05 \%$; summarized in Andersen et al., 2016), it follows that our data are significantly fractionated from average continental crust.

\section{Discussion}

Our record shows distinct and reproducible stratigraphic trends in $\delta^{238} \mathrm{U},[\mathrm{U}]$, and REE anomalies through the Cryogenian nonglacial interlude. Specifically, $\delta^{238} \mathrm{U}$ decreases at the Taishir $\delta^{13} \mathrm{C}$ excursion to a minimum of $-0.85 \%$. For comparison, the $\delta^{238} \mathrm{U}$ of carbonates deposited during periods of anoxia in the Phanerozoic (Early Triassic) reach values as low as $-0.77 \%$ (Lau et al., 2016). 


\subsection{Influences on carbonate $\delta^{238} \mathrm{U}$ and [U]}

Because uranium reduction in marine sediments affects both the solubility and ${ }^{238} \mathrm{U} /{ }^{235} \mathrm{U}$ of the aqueous species, changes in redox conditions should result in covarying behavior in seawater $\delta^{238} \mathrm{U}$ and [U]. For example, an areal expansion of oxygenated seafloor should be reflected in more positive $\delta^{238} \mathrm{U}$ values and higher [U] (Lau et al., 2016). However, neither the records for individual stratigraphic sections nor the compiled records exhibit covarying trends in $\delta^{238} \mathrm{U}$ and [U]. In this section, we discuss possible explanations for these differences, including diagenetic alteration, carbonate mineralogy, and local redox conditions.

\subsubsection{Diagenetic considerations}

Uranium is present in trace concentrations in limestone and thus the concentration and isotopic composition are subject to alteration from interaction with diagenetic fluids. Deep burial brines are generally reducing, and as such would be expected to have low $\delta^{238} \mathrm{U}$ and [U] values relative to seawater and thus less leverage to affect carbonate compositions. Oxygen isotope ratios depleted in ${ }^{18} \mathrm{O}$ can indicate post-depositional alteration, but no statistically significant correlations with $\delta^{238} \mathrm{U}$ are observed (Table S2). In addition, $\mathrm{Mn} / \mathrm{Sr}$ ratios are generally very low, with almost all of the data falling below $\mathrm{Mn} / \mathrm{Sr}<0.4$. In contrast, we observe significant correlations between [Fe] with $\delta^{238} \mathrm{U}$ for F949 and [U] for both sections (Table S2, Fig. 4), suggesting that local redox conditions (which may enrich [Fe]) could impact the uranium proxy. The correlation coefficient between [Fe] and $\delta^{238} \mathrm{U}$ for F949 (Spearman's $\rho=0.71$ ) indicates that these parameters are strongly linked. However, this appears to be driven by $\mathrm{T} 1$ data, which may reflect post-glacial non-steady-state conditions (Fig. S2).

A simple model of carbonate diagenesis in the presence of a seawater-derived early diagenetic fluid (Fig. 5; modified after Banner and Hanson, 1990) demonstrates that the order in which concentrations and isotopic compositions of elements of interest are reset is: $\delta^{18} \mathrm{O},[\mathrm{Sr}],[\mathrm{U}]$ and $\delta^{238} \mathrm{U}, \delta^{13} \mathrm{C}$. Furthermore, [U] and $\delta^{238} \mathrm{U}$ in aragonite-which is the likely primary carbonate polymorph given a mean and maximum [Sr] of $890 \mathrm{ppm}$ and $4300 \mathrm{ppm}$, respectively-are altered at a higher water-to-rock ratio than in calcite due to the difference in partition coefficients. Therefore, $\mathrm{U}$ should be more robust than $\mathrm{Sr}$ with respect to diagenetic alteration, and requires a greater degree of exchange in order to be altered in aragonite than in calcite. Although $\delta^{18} \mathrm{O}$ values through our sections appear to be reset, ${ }^{87} \mathrm{Sr} /{ }^{86} \mathrm{Sr}$ values from Mongolia are reproduced in nearby Cryogenian sections and are well within the range of typical seawater (Shields et al., 2002; Bold et al., 2016). Coupled to aragonite precipitation, these samples thus appear to preserve the $\mathrm{Sr}$ and $\mathrm{U}$ isotopic compositions of contemporaneous seawater. A description of the early diagenetic model and the parameterization are provided in the Supplementary Materials and Table S3.

Dolomitization and high organic carbon content in sediments have been proposed to increase authigenic uranium reduction (McManus et al., 2005; Morford et al., 2009; Romaniello et al., 2013). These processes would result in pore water [U] and $\delta^{238} \mathrm{U}$ values that do not reflect seawater, which would then be incorporated into early diagenetic carbonate cements. The TOC of samples from F949 are very low, with a mean of $0.08 \%$ and a maximum of $0.3 \%$ (Table $\mathrm{S} 1$ ). In addition, there is no significant correlation between $\mathrm{Mg} / \mathrm{Ca}$ or TOC and the combined [U] and $\delta^{238} \mathrm{U}$ records (Table S2, Fig. 4), suggesting that neither dolomitization nor organic carbon content systematically altered the primary record.

Changes in lithology can also affect the penetration of diagenetic fluids. Sediments with higher porosities (e.g., ooids, packstones, grainstones) are more prone to water-rock interaction than are muddy sediments, resulting in a higher likelihood for exchange.

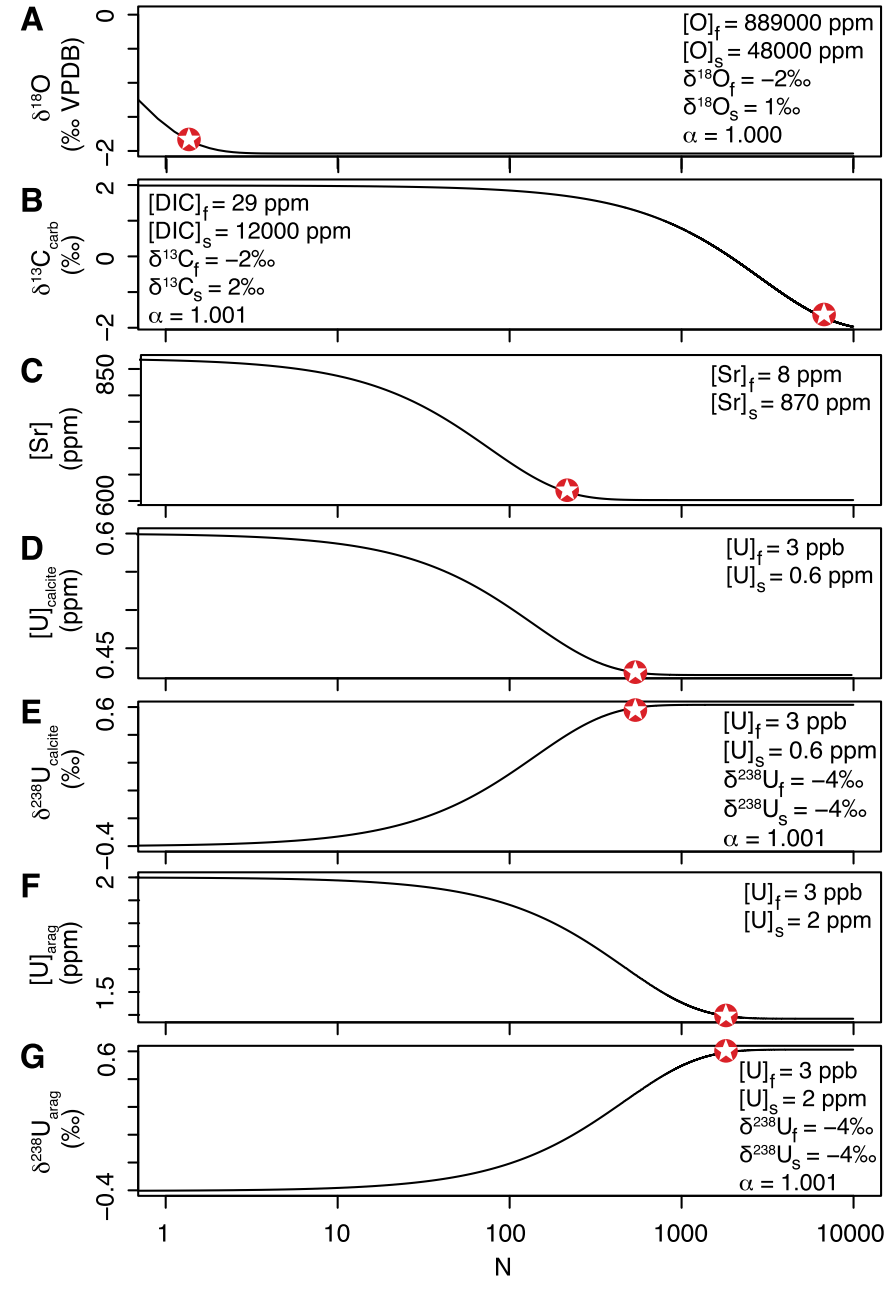

Fig. 5. Open-system model of the evolution of carbonate diagenesis for (A) $\delta^{18} \mathrm{O}$ (B) $\delta^{13} \mathrm{C}$, (C) [Sr], (D) [U], and (E) $\delta^{238} \mathrm{U}$ for a hypothetical calcite rock interacting with a fluid derived from seawater with $[\mathrm{Ca}]=600 \mathrm{ppm}$ (after Banner and Hanson, 1990). (F) [U] and $(G) \delta^{238} \mathrm{U}$ for a hypothetical aragonite rock. $N$ is the cumulative water-to-rock ratio. Both the rock $(s)$ and fluid $(f)$ have compositions and distribution coefficients $\left(K_{d}\right)$ similar to modern carbonate sediments and seawater, respectively. The stars mark the water-to-rock ratio where $95 \%$ of the chemical constituent has been altered.

Despite significant facies changes within multi-meter thick parasequences, the $\delta^{238} \mathrm{U}$ and [U] values remain relatively invariant, particularly for T3. Therefore, neither [U] nor $\delta^{238} \mathrm{U}$ values appear to be strongly controlled by local sedimentary facies. More importantly, reproducibility of the overall shift in mean $\delta^{238} \mathrm{U}$ values across the basin, in sections separated by $\sim 75 \mathrm{~km}$ that exhibit large differences in facies, suggests a primary signature.

In addition, uranium can be influenced by the amount of detrital input. Although $\delta^{238} \mathrm{U}$ is statistically correlated with [Al] as a proxy for detrital input (likely sourced from siliciclastic clays), this correlation may be attributed to high detrital contributions that correspond to the most positive $\delta^{238} \mathrm{U}$ values measured at the base of the sections (Fig. S2). If only data from T2 and T3 are analyzed, the correlation is no longer significant ( $p$-value $=0.07$ ). Moreover, clay contents are low throughout: samples contain an average of 96.7\% carbonate content.

Although minor diagenetic variability in the $\delta^{238} \mathrm{U}$ and [U] compositions of individual samples is unavoidable, the lack of statistical correlation between our $\delta^{238} U$ data, geochemical indicators of diagenesis, and detrital input suggests that the uranium in limestone sections of the Taishir Formation was not pervasively nor systematically altered. Therefore, we interpret the general trends 
in the $\delta^{238} \mathrm{U}$ data as reflecting primary carbonate composition, and focus on the overall patterns in the mean values.

\subsubsection{Mineralogical considerations}

The concentration of uranium in carbonate sediments is dependent on the carbonate mineralogy, and can vary depending on $\mathrm{pH}$ and temperature. The distribution coefficient of uranium into aragonite $\left(D_{U}\right)$ has been experimentally determined to be higher than for calcite (Meece and Benninger, 1993). The [Sr] and Sr/Ca (Fig. S2, Table S1) suggest that the primary composition was aragonitic for much of this stratigraphic interval, but diagenetic recrystallization to calcite may have resulted in changes in [U]. Higher seawater [Ca] would also result in a larger $D_{U}$; however, reliable constraints on Cryogenian seawater [Ca] are not currently available.

In contrast, the effect of mineralogy and carbonate ion concentration on ${ }^{238} \mathrm{U} /{ }^{235} \mathrm{U}$ is more limited. Uranium isotope measurements of aragonite and high-magnesium calcite primary precipitates exhibit no offset from seawater (Romaniello et al., 2013). Moreover, laboratory-precipitated calcite and aragonite at $\mathrm{pH} \sim 8.5$ showed only minor $(<0.13 \%)$ fractionation between the liquid medium and the solid (Stirling et al., 2015; Chen et al., 2016). In contrast, at $\mathrm{pH} \sim 7.5$ the precipitates of both polymorphs exhibit no fractionation (Chen et al., 2016). Based on these observations, changing carbonate mineralogy can result in large differences in concentrations but only small changes in the isotopic composition. Thus, the decoupling of [U] from $\delta^{238} \mathrm{U}$ may be attributed to possible mineralogical shifts that affect only the reliability of the carbonate [U] paleoredox proxy and not $\delta^{238} \mathrm{U}$. In our data, [U] values exhibit significant correlations with a larger number of proxies for alteration than $\delta^{238} \mathrm{U}$, highlighting the greater number of factors that can affect [U] relative to $\delta^{238} \mathrm{U}$ (Table S2). Additionally, [U] is positively correlated with $\mathrm{Sr} / \mathrm{Ca}$, as would be expected if aragonite precipitated with higher [Sr], whereas a significant correlation between $\delta^{238} \mathrm{U}$ and $\mathrm{Sr} / \mathrm{Ca}$ is not observed.

\subsubsection{REE and redox conditions of the overlying water column}

Unlike the other REE, which are strictly trivalent in the oceans, the solubility of Ce can vary depending on whether it exists as $\mathrm{Ce}(\mathrm{III})$ or $\mathrm{Ce}(\mathrm{IV})$. The redox state is modulated by the presence of manganese oxide and/or bacteria, where Ce is oxidized by and adsorbed onto mineral surfaces (summarized in Ling et al., 2013). Thus, the concentration of Ce relative to the other REE is associated with dissolved oxygen concentrations, and can be used to infer redox conditions of the overlying water column (Ling et al., 2013). Because locally anoxic conditions can affect $U$ incorporation into carbonates (Romaniello et al., 2013), characterizing local redox conditions is critical for determining if either carbonate $\delta^{238} \mathrm{U}$ or [U] reflect global seawater composition.

All of the $\mathrm{Ce} / \mathrm{Ce}^{*}$ values are greater than observed in the modern open ocean, which ranges from 0.05 to 0.35 , suggesting that ocean oxygenation must have been less extensive (Fig. 3). In general, $\mathrm{Ce} / \mathrm{Ce}^{*}$ in $\mathrm{T} 1$ (basal $20 \mathrm{~m}$ ) and the upper half of $\mathrm{T} 3$ are greater than $\mathrm{Ce} / \mathrm{Ce}^{*}$ values of 0.6 to 1.0 that characterize euxinic waters of the Black Sea (Ling et al., 2013), and thus are indicative of a local water column that was at least partially anoxic. In contrast, in the upper portion of $\mathrm{T} 1$ and throughout $\mathrm{T} 2, \mathrm{Ce} / \mathrm{Ce}^{*}$ are lower and reach a minimum of 0.5 , in agreement with a $\mathrm{Ce}$ depletion identified by Shields et al. (2002). Cerium depletion in $\mathrm{T} 2-$ where $\mathrm{Ce} / \mathrm{Ce}^{*}$ are significantly less than $\mathrm{Ce} / \mathrm{Ce}^{*}$ for $\mathrm{T} 1$ (mean difference $=0.43, p$-value $<0.001$ ) and T3 (mean difference $=$ $0.18, p$-value $<0.001)$-may reflect an increase in global marine oxidation (likely from higher atmospheric $\mathrm{pO}_{2}$ ) or basin shallowing with deposition above the redox-cline (Ling et al., 2013; Shields et al., 2002; see Supplementary Materials).

Under both scenarios, it is likely that the oxidation of the overlying water column was greatest during T2 and lowest during the basal T1. In the upper T3 member, the lack of Ce depletion suggests F949 was anoxic (corresponding data for F1125 were not collected). If such anoxic waters $\left(\mathrm{Ce} / \mathrm{Ce}^{*} \geq 0.6\right)$ influenced local pore waters and resulted in greater reduction of uranium, the $\delta^{238} \mathrm{U}$ of authigenically precipitated U(IV) would be predicted to be heavier than seawater (Romaniello et al., 2013). However, stratigraphic intervals with $\mathrm{Ce} / \mathrm{Ce}^{*}$ indicating anoxic conditions correspond to samples with more negative $\delta^{238} \mathrm{U}$ values, opposite to the predicted result if pore water anoxia was the primary control on the observed uranium isotopic trend.

From these observations, we conclude that [U] values are subject to a larger range of local controls during deposition, whereas $\delta^{238} \mathrm{U}$ is more likely to preserve changes in global average seawater composition.

\subsection{Interpretation as seawater $\delta^{238} \mathrm{U}$}

As described in section 4.1.2, uranium is not significantly fractionated when incorporated into primary precipitates. In contrast, bulk carbonate $\delta^{238} \mathrm{U}$ in modern sediments in the Bahamas are $\sim 0.2 \%$ more positive than seawater (Romaniello et al., 2013). However, the prevalence of this offset globally, and the responsible mechanism, is not yet fully understood. Here, we assume negligible fractionation between seawater and our limestone samples, and note that given a measurable yet constant offset, the observed magnitude of change in $\delta^{238} \mathrm{U}$ with time would remain.

A major control on seawater $\delta^{238} \mathrm{U}$ is the extent of seafloor anoxia, but other factors must be considered. To explore the importance of these other controls, we use a uranium box model for seawater $\delta^{238} \mathrm{U}$ (modified from Lau et al., 2016):

$$
\begin{aligned}
\frac{d N_{s w} \cdot \delta^{238} \mathrm{U}}{d t}= & J_{\text {riv }}\left(\delta^{238} \mathrm{U}_{\text {riv }}-\delta^{238} \mathrm{U}\right)-J_{\text {anox }} \Delta_{\text {eff }}-J_{\text {sorp }} \Delta_{\text {sorp }} \\
& -J_{\text {subox }} \Delta_{\text {subox }}-J_{\text {other }} \Delta_{\text {other }}
\end{aligned}
$$

where $N_{S w}$ is the oceanic uranium inventory, $\delta^{238} \mathrm{U}$ is the value of seawater, $\delta^{238} \mathrm{U}_{\text {riv }}$ is the value of the riverine source, and $\Delta$ is the fractionation factor associated with each flux. Specifically, $\Delta_{\text {eff }}$ is the effective fractionation factor associated with anoxic sediment deposition (Andersen et al., 2014). We simplify the inputs to $J_{\text {riv }}$, the riverine flux. Removal into anoxic sediments, $J_{a n o x}$, is defined as:

$J_{\text {anox }}=K_{\text {anox }} \cdot N_{s w} \cdot f_{\text {anox }}$

where $f_{\text {anox }}$ is the fraction of seafloor impacted by bottom-water anoxia and $K_{\text {anox }}$ is the associated rate constant. The remaining output fluxes not associated with anoxic sediments-adsorption to Fe- and Mn-oxides ( $\left.J_{\text {sorp}}\right)$, sequestration into suboxic sediments (continental margin sediments with $\leq 10 \mu \mathrm{mol} / \mathrm{L}\left[\mathrm{O}_{2}\right], J_{\text {subox }}$ ), and hydrothermal alteration and precipitation into biogenic carbonate and silica (combined into $J_{\text {other }}$ )-can be grouped into the term Jna:

$J_{n a}=J_{\text {sorp }}+J_{\text {subox }}+J_{\text {other }}=K_{n a} \cdot N_{s w} \cdot\left(1-f_{\text {anox }}\right)$

where $K_{n a}$ is a rate constant. Each flux is defined as a proportion of $J_{n a}$ :

$J_{\text {sorp }}=p_{\text {sorp }} \cdot J_{n a}$

$J_{\text {subox }}=p_{\text {subox }} \cdot J_{\text {na }}$

$J_{\text {other }}=p_{\text {other }} \cdot J_{\text {na }}$

The $p_{\text {sorp }}, p_{\text {subox }}$, and $p_{\text {other }}$ terms represent the proportion of their respective fluxes relative to $J_{n a}$, where $p_{\text {sorp }}+p_{\text {subox }}+p_{\text {other }}=1$. The proportion terms, $p$, and rate constants, $K_{\text {anox }}$ and $K_{n a}$, are calculated based on the modern uranium budget, summarized in Tissot and Dauphas (2015) and Andersen et al. (2016). We note 

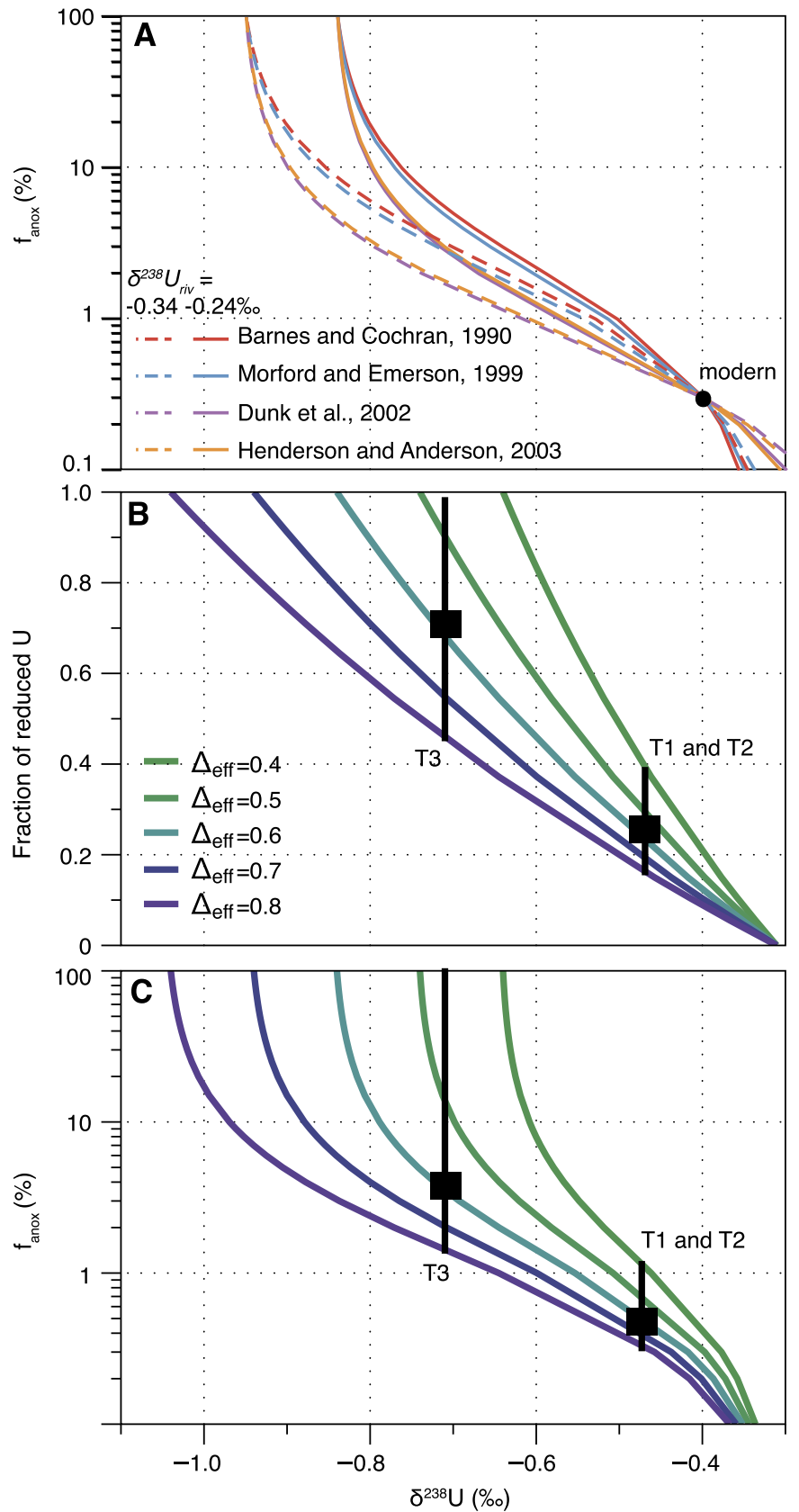

Fig. 6. Steady-state relationship between $\delta^{238} U$ and $f_{\text {anox }}$, and its sensitivity to (A) the modern range of isotopic composition of riverine $\mathrm{U}\left(\delta^{238} \mathrm{U}_{\text {riv }}\right)$ and parameterization of U fluxes for budgets from Barnes and Cochran (1990), Morford and Emerson (1999), Dunk et al. (2002), and Henderson and Anderson (2003). To determine the sensitivity to variations in the fractionation factor $\left(\Delta_{\text {eff }}\right)$ associated with uranium reduction, (B) the fraction of reduced $U$ relative to the total sinks and (C) $f_{a n o x}$ for $\Delta_{\text {eff }}$ from -0.4 to $-0.8 \%$ are also calculated. Initial parameterization for all models is determined assuming steady state for the modern $\left(\delta^{238} \mathrm{U}=-0.4 \%, f_{\text {anox }}=0.3 \%\right)$. Black bars indicate the mean $\delta^{238} \mathrm{U}$ value for T3 and combined T1 and T2, where the square represents the fraction of reduced $U$ and $f_{a n o x}$ values using the $\Delta_{\text {eff }}$ of the modern ocean (Andersen et al., 2014) and the spread of the bar represents the uncertainty introduced by different $\Delta_{\text {eff }}$ values. (For interpretation of the references to color in this figure, the reader is referred to the web version of this article.)

that a change in global marine oxygenation will simultaneously affect $f_{\text {anox }}, p_{\text {sorp }}$, and $p_{\text {subox }}$; however, the relationships linking these sinks are complex and this model is designed to provide a first-order evaluation of fluctuating anoxic conditions.

The steady-state relationship between $f_{\text {anox }}$ and $\delta^{238} \mathrm{U}$ can be evaluated using equations (1) to (6). Because the fluxes and isotopic compositions of the modern uranium cycle are not pre- cisely known, the relationship between $f_{a n o x}$ and $\delta^{238} \mathrm{U}$ is dependent on the parameterization. To illustrate the sensitivity of the model to these uncertainties, we parameterize the fluxes with previously published budgets for the modern $U$ cycle, and for $\delta^{238} \mathrm{U}_{\text {riv }}=-0.24 \%$ (Noordmann et al., 2015) (Fig. 6A, solid lines) and $=-0.34 \%$ (Andersen et al., 2016) (Fig. 6A, dashed lines). Seawater $\delta^{238} \mathrm{U}$ is most sensitive when $f_{\text {anox }}<10 \%$. Above this, the estimated $f_{\text {anox }}$ can vary by a maximum of $5 \%$ at $\delta^{238} \mathrm{U}=-0.75 \%$. Variations in $\delta^{238} \mathrm{U}_{\text {riv }}$ for the same budget parameterization can also produce uncertainties in $f_{\text {anox }}$ of similar magnitudes. However, the resulting uncertainties are non-linear, and decrease at lower $f_{\text {anox }}$ and more positive $\delta^{238} U$. Despite these uncertainties, this modeling approach is able to provide first-order estimates of fluctuating $f_{\text {anox }}$ through time, and in the following sections we use the U budget estimated in Morford and Emerson (1999) and assume $\delta^{238} \mathrm{U}_{\text {riv }}=-0.27 \%$ (Andersen et al., 2016). The initial values for the model are provided in Table S4, and additional details are described in the Supplementary Materials.

\subsubsection{Sensitivity to variations in the fractionation factor}

In addition to changes in the mass balance and isotopic composition of seawater uranium, changes in the fractionation factor could also result in changes in seawater $\delta^{238} \mathrm{U}$. As described in section 4.1.2, $\delta^{238} \mathrm{U}$ is slightly fractionated $(<0.13 \% 0)$ in aragonite precipitated at a pH of 8.5 (Chen et al., 2016). While this fractionation may be partly responsible for some differences in our record, it is too minor to fully explain the changes in $\delta^{238} \mathrm{U}$. Laboratory studies of microbially mediated uranium reduction estimate fractionation factors ranging from 1 to $1.2 \%$, whereas a small to negligible fractionation is observed during abiotic reduction (Stirling et al., 2015; Stylo et al., 2015). However, in modern anoxic basins, the observed offset between seawater and reduced marine sediments is closer to $0.6 \%$, and is considered an effective fractionation factor $\left(\Delta_{\text {eff }}\right)$, or the integrated fractionation between seawater and the sediment column where biotic reduction is occurring (Andersen et al., 2014). Competing processes such as adsorption to organic matter may also dampen this fractionation (Hinojosa et al., 2016). As a result, $\Delta_{\text {eff }}$ may vary depending on factors such as the degree of uranium drawdown, organic matter content, basin connectivity with the open ocean, or oxygen penetration into pore waters (Andersen et al., 2014; Hinojosa et al., 2016). Moreover, the behavior of uranium under ferruginous conditions may differ from those in euxinic basins, which are used to calibrate our model.

To explore the sensitivity of our estimates of anoxia to these assumptions, we calculate steady-state relationships between $\delta^{238} \mathrm{U}$ and $f_{\text {anox }}$, as a function of $\Delta_{\text {eff }}$, using equations (1) through (3) (Figs. 6B, C; details described in the Supplementary Materials). Regardless of the value of $\Delta_{\text {eff }}$, the resulting estimates for $f_{\text {anox }}$ for the mean values of combined T1 and T2 do not overlap with T3, suggesting that our conclusions are not dependent on the assumed mechanism of $U$ reduction and fractionation. In other words, if the change in $\delta^{238} \mathrm{U}$ in our record is attributed to variations in $\Delta_{\text {eff }}$, this would require a change of $>0.4 \%$-an unlikely scenario given our current understanding of uranium.

\subsubsection{Mass balance model results}

Although local processes undoubtedly influence the uranium composition of any geological sample, the most consistent explanation for the statistically supported trends in $\delta^{238} \mathrm{U}$ across our study sites is a primary signal reflecting a change in the uranium composition of seawater of $\sim 0.2 \%$. From the Taishir excursion through T3, $\delta^{238} \mathrm{U}$ values near $-0.7 \%$ support pervasive anoxia, corresponding to $\sim 5 \%$ of the seafloor being anoxic (Fig. $6 \mathrm{C}$, blue line) relative to the modern ocean, where only 0.2 to $0.3 \%$ of the seafloor is anoxic (Tissot and Dauphas, 2015). We focus on modeling the more positive $\delta^{238} \mathrm{U}$ values in $\mathrm{T} 1$ and $\mathrm{T} 2$, and 

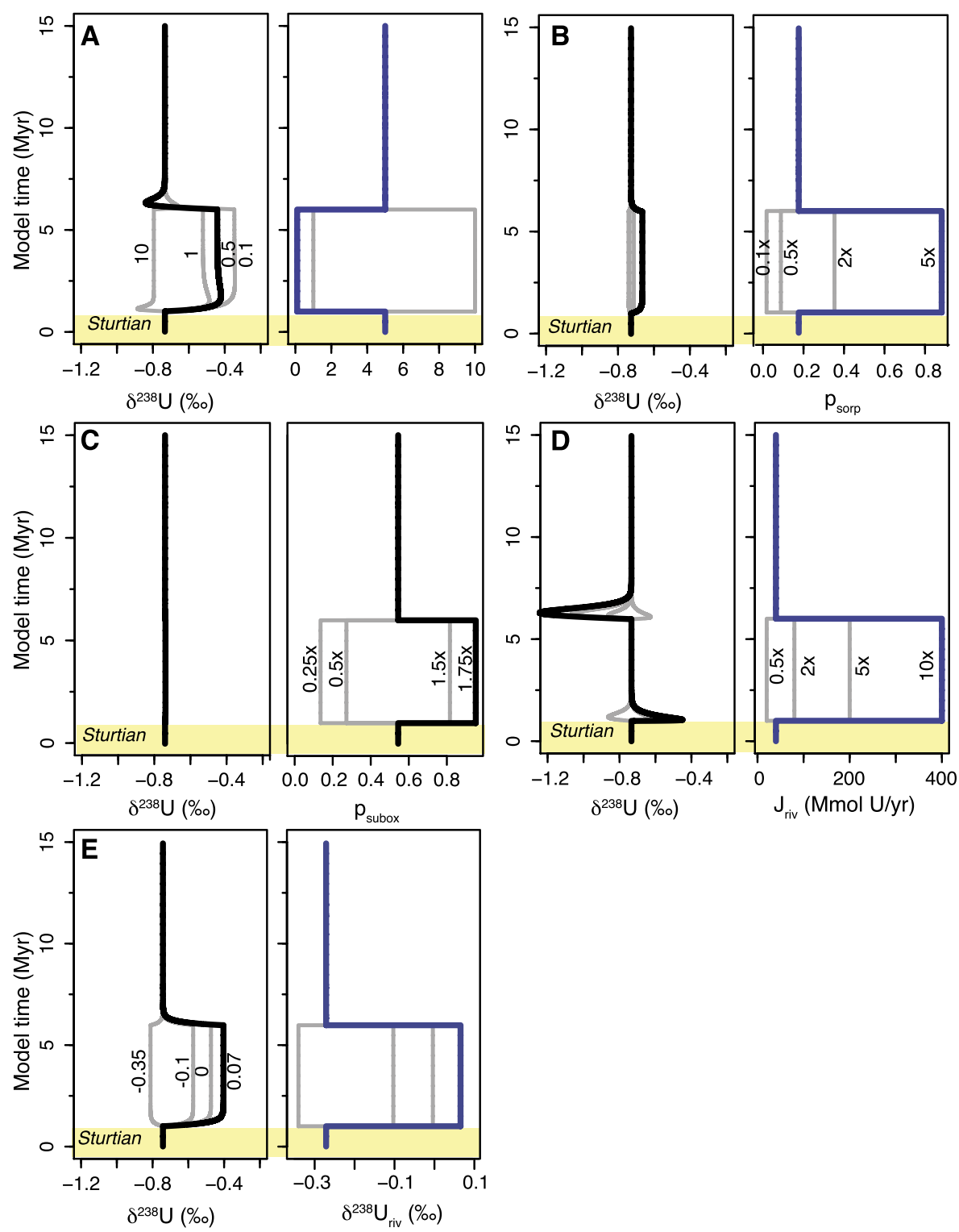

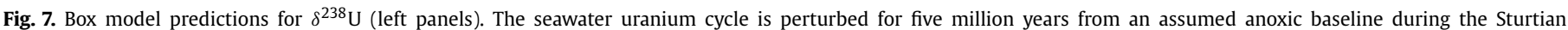

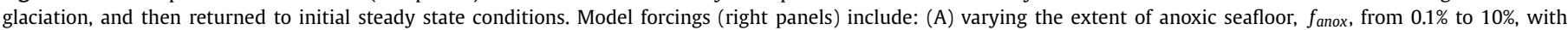

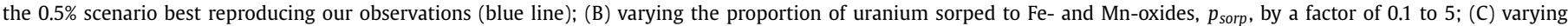

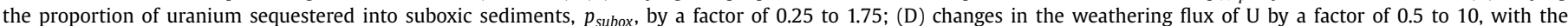

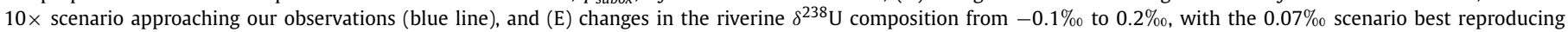

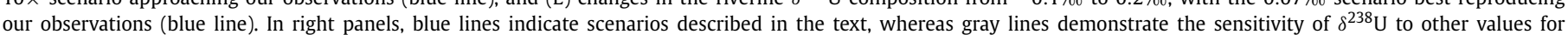
each forcing. (For interpretation of the references to color in this figure legend, the reader is referred to the web version of this article.)

examine the parameters that can explain these modern-seawaterlike values relative to an anoxic baseline (T3) using equations (1) through (6). Though paleoredox conditions during the Sturtian glaciation are poorly constrained, the preponderance of basin-wide indicators for ferruginous conditions preceding and following the glaciation suggests that the ocean was anoxic (Canfield et al., 2008; Tahata et al., 2015; Zhang et al., 2015). Under the assumption that the initial state of the ocean was similar to conditions following the Taishir excursion, we set initial parameters to an anoxic baseline based on the 5\% estimate for T3 (Table S5). Carbonates deposited under anoxic conditions may be offset by $\sim+0.2 \%$ from seawater (Romaniello et al., 2013); such an effect would result in an underestimate in the modeled extent of anoxia.

Using the mass balance model of the $\delta^{238} \mathrm{U}$ of seawater (Equations (1)-(6)), we consider how five controls could result in seawater $\delta^{238} \mathrm{U}$ values similar to the value for T2 (Fig. 7). First, we adjust the degree of ocean anoxia by decreasing $f_{\text {anox }}$ to $0.5 \%$, which causes seawater $\delta^{238} \mathrm{U}$ to increase to $-0.5 \%$ (Fig. 7A). Second, we increase $p_{\text {sorp }}$ and $p_{\text {subox }}$, the proportion of $U$ adsorbed to Fe- and Mn-oxides $\left(J_{\text {sorp }}\right)$ and sequestered into suboxic sediments $\left(J_{\text {subox }}\right)$, respectively. Both of these sinks are associated with small fractionations: $-0.24 \%$ for $J_{\text {sorp }}$ (Goto et al., 2014) and $0.1 \%$ for $J_{\text {subox }}$ (Tissot and Dauphas, 2015), although this latter value is not well constrained. By increasing $p_{\text {sorp }}$ by a factor of five, $\delta^{238} \mathrm{U}$ values increase by $<0.1 \% 0$ (Fig. 7B). An increase in $p_{\text {subox }}$ by a factor of 1.75 results in an imperceptible increase in $\delta^{238} \mathrm{U}$ (Fig. 7C). Thus, both of these fluxes have limited leverage on seawater $\delta^{238} \mathrm{U}$. In the last two scenarios, we experiment with changes in the riverine delivery of uranium. By increasing this input flux by an order of magnitude from an initial value of $40 \mathrm{Mmol} \mathrm{U} / \mathrm{yr}$ (Morford and Emerson, 1999), $\delta^{238} \mathrm{U}$ values undergo a transient positive increase up to $\sim-0.4 \%$ o before regressing to the initial value (Fig. $7 D$ ). On 

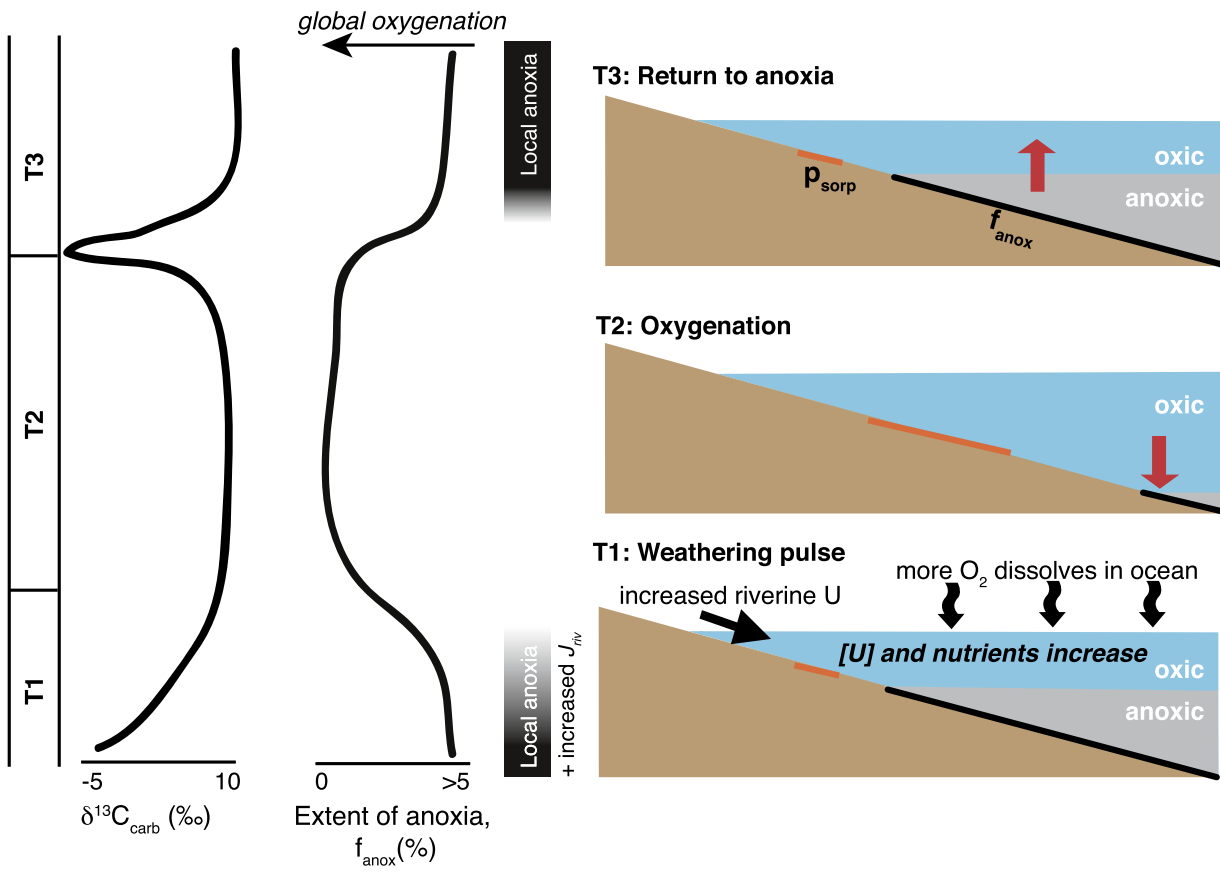

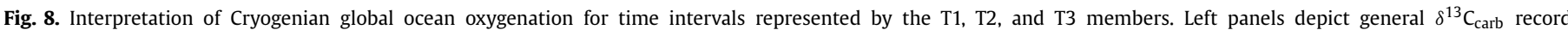

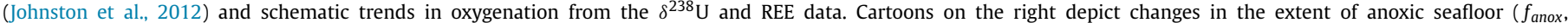

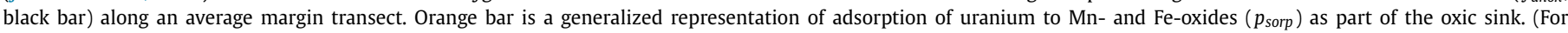
interpretation of the references to color in this figure legend, the reader is referred to the web version of this article.)

the other hand, if the isotopic composition of the riverine flux is changed from the modern value of $-0.27 \%$ to $0.07 \%$, the predicted $\delta^{238} \mathrm{U}$ values match the observed data for T2 (Fig. 7E), but is short-lived. These changes in riverine flux and composition represent extreme scenarios of weathering or changing weathered lithology, where the shift in $\delta^{238} \mathrm{U}_{\text {riv }}$ would require all of the riverine uranium to be derived from black shale with a mean $\delta^{238} \mathrm{U}$ composition of $\sim 0.03 \%$ (Andersen et al., 2016 and the references therein).

The modeling results suggest that the mean $\delta^{238} \mathrm{U}$ value for the T1 member, including the post-Sturtian cap carbonate, may represent a combination of an elevated weathering flux and lowoxygen conditions. To illustrate, an abrupt increase in weathering could result in a transient positive excursion in $\delta^{238} \mathrm{U}$ (Fig. 7C). Even in the presence of an anoxic ocean, these factors could result in seawater $\delta^{238} \mathrm{U}$ values that represent a non-steady-state condition intermediate between a very negative, anoxic signature, and a more positive, weathering signature.

The $\delta^{238} \mathrm{U}$ values observed in the T2 member cannot be explained by changing the weathering flux, composition of riverine uranium, or the fractionation factor (Fig. 6, Figs. 7D and 7E). Rather, the modeling results emphasize that redox conditions are the primary control on seawater $\delta^{238} \mathrm{U}$ (Fig. 7A), and thus the shift in $\delta^{238} \mathrm{U}$ between the T2 and T3 stratigraphic zones is best explained by an approximately factor-of-ten increase in $f_{\text {anox }}$, from $0.5 \%$ to $5 \%$ of the seafloor, although the magnitude is an estimate due to uncertainty regarding the relationship between $\delta^{238} \mathrm{U}$ to $f_{\text {anox }}$ (Fig. 6A). An increase in the adsorption flux to Mn- and Feoxides acts as a secondary control on seawater $\delta^{238} \mathrm{U}$, and would still require a change in $f_{\text {anox }}$ in order to match our observations. The onset of $\delta^{238} \mathrm{U}$ values near modern seawater values in T1 may be attributed to a change in the weathering flux and source material following the Sturtian Snowball Earth, but these factors cannot be the primary mechanism that explains the mean $\delta^{238} \mathrm{U}$ value of $-0.48 \%$ in T2. As a result, our observations are best explained by a significant decrease in global anoxia following the Sturtian glaciation and preceding the Taishir excursion (Fig. 8).

\subsection{Implications for the Neoproterozoic oxygenation event}

Mass-balance analysis of the sensitivity of $\delta^{238} \mathrm{U}$ to redox controls suggests the area of anoxic sediments contracted and the deep oceans became oxygenated following the Sturtian Snowball Earth (Fig. 8). The oceans then became more anoxic prior to the Marinoan glaciation. Our reconstruction of Cryogenian global marine oxygenation and return to anoxic conditions suggests that the NOE was not an irreversible, stepwise increase in oxygenation, and that any long-term change was punctuated by large fluctuations. Previous studies using local proxies (Fe speciation and isotopes, and metal enrichments) indicate the deposition of anoxic black shales immediately following the Sturtian glaciation (Canfield et al., 2008; Feng et al., 2010; Kunzmann et al., 2015; Li et al., 2012; Sperling et al., 2016; Tahata et al., 2015; Zhang et al., 2015). However, these studies are dominated by data from the glacioeustatic transgressive-systems tracts (TST), which likely led to local organic loading and anoxia. This interval is represented in our data from $\mathrm{T} 1$, whereas data from $\mathrm{T} 2$ and $\mathrm{T} 3$ encompass a longer, multi-million-year record. Because our record of oxygenation in T2 generally overlies the previously studied strata, these periods of observed local and short-term anoxia would have resulted in organic burial that may have led to broader oxygenation.

The mechanisms that led to ocean oxygenation following the Sturtian glaciation may be similar to those that are hypothesized for temporary oxygenation after the Marinoan glaciation, interpreted from Marinoan cap carbonate $\delta^{34} \mathrm{~S}$ records and trace metal (Mo and U) enrichments (Fike et al., 2006; Sahoo et al., 2012). Sahoo et al. (2012) propose that postglacial weathering fertilized the oceans with phosphate, stimulating organic carbon burial and leading to higher atmospheric $\mathrm{pO}_{2}$ levels and hence global ocean oxygenation. This hypothesis is supported by an increase in radiogenic $\mathrm{Sr}$ isotopes from 0.7068 to 0.7075 (Bold et al., 2016) following the Sturtian glaciation. In comparison to our interpretation of post-Sturtian oxygenation on the order of $>1 \mathrm{Ma}$, post-Marinoan oxygenation in Ediacaran oceans appears to have been short-lived (Sahoo et al., 2012). Alternatively, the rise of macroscopic eukary- 
otes (e.g., Cohen and Macdonald, 2015) may have resulted in larger sinking organic particles that increased organic carbon burial and consequently, oxygen levels (Lenton et al., 2014).

Uranium isotope evidence for temporary oxygenation in the Cryogenian is consistent with a role for increased oxygen availability in the early divergence of major animal clades. The appearance of animals has long been proposed to have required widespread marine oxygenation (reviewed in Och and Shields-Zhou, 2012). Because the Cryogenian oceans did not consistently maintain a high degree of oxygenation, it is possible that these conditions were only sufficient to support small-bodied forms with low metabolic rates. Such a scenario is consistent with biomarker evidence for abundant demosponges during the Cryogenian nonglacial interval (Love et al., 2009) and possible sponge body fossils (Maloof et al., 2010), as sponges do not require high levels of oxygen (Mills et al., 2014). This scenario is also consistent with the absence of macroscopic bilaterian body fossils in the strata and molecular clock evidence that only simple forms with poor preservation potential, such as demosponges and cnidarians, had diverged by this time (Erwin et al., 2011). Later Cryogenian return to globally anoxic conditions may have limited animals (sponges) to oxygen oases, further inhibiting the evolution of the larger and more active triploblastic animals until Ediacaran time.

\subsection{Implications for the Neoproterozoic carbon cycle}

The relationship between the onset of negative $\delta^{238} \mathrm{U}$ values and the Taishir excursion suggests a causal link between this perturbation to the carbon cycle and changing redox conditions. Covariance in carbonate and organic carbon $\delta^{13} \mathrm{C}$ rules out a diagenetic explanation, and thus the excursion may be attributed to an input of isotopically negative, reduced carbon-such as the oxidation of methane or organic matter (Johnston et al., 2012), or a decrease in the authigenic carbonate sink. The release of methane could explain the Taishir excursion and lead to global warming (Bjerrum and Canfield, 2011), resulting in a decrease in oxygen solubility and an increase in respiration rates leading to widespread anoxia. Alternatively, increased oxidation of organic matter, either of a large dissolved organic carbon pool (Rothman et al., 2003) or of organic matter in shelf sediments (Johnston et al., 2012) would draw down oxygen from the atmosphere and return the ocean to an anoxic state.

Using t-tests, we determined the optimal binning of our $\delta^{238} \mathrm{U}$ dataset into two temporal groups (Fig. S3). We obtain the lowest $p$-value $(0.00001)$ and highest F-ratio $(23.3)$ when the $\delta^{238} \mathrm{U}$ dataset is divided into two bins defined by the start of the Taishir excursion. Thus, the $\delta^{238} \mathrm{U}$ record supports the oxidation of reduced carbon as a cause for the large negative $\delta^{13} \mathrm{C}_{\text {carb }}$ perturbation of the Cryogenian. However, modeling efforts have raised concerns about depletion of oxidants during rapid oxidation of organic matter as a hypothesis to drive large Neoproterozoic $\delta^{13} \mathrm{C}_{\mathrm{carb}}$ excursions (Bristow and Kennedy, 2008). Additionally, $\delta^{13} \mathrm{C}_{\text {carb }}$ values in both the T2 and T3 members are $>+8 \%$, and yet $\delta^{238} \mathrm{U}$ values imply a large difference in the degree of seafloor anoxiaconditions that are difficult to reconcile using only one driving mechanism. If explained solely by changes in the proportion of the burial fluxes of carbon, elevated $\delta^{13} \mathrm{C}_{\text {carb }}$ would require $f_{\text {org }}$ of $\sim 0.6$ (compared to the modern value of $\sim 0.2$ ), resulting in a rise in atmospheric $\mathrm{pO}_{2}$ and depletion of the surface reservoir of carbon or shutdown of carbonate deposition (Bachan and Kump, 2015). The $\delta^{238} \mathrm{U}$ data presented herein are consistent with authigenic carbonate precipitation as a much larger sink than in the modern during the positive plateaus of $\delta^{13} \mathrm{C}_{\mathrm{carb}}$ in $\mathrm{T} 2$ and $\mathrm{T} 3$ (e.g., Schrag et al., 2013). However, this flux is difficult to quantify, and $\delta^{13} C_{\text {carb }}$ cements with extremely depleted values have not yet been shown to be more common in the Cryogenian nonglacial interlude relative to other intervals in Earth history. Although interpretations for the decoupling between redox conditions and $\delta^{13} \mathrm{C}_{\text {carb }}$ values are still incomplete, our observations are consistent with de-oxygenation occurring simultaneously with an addition of isotopically light carbon.

\section{Conclusion}

Our uranium isotope constraints on marine redox conditions during the Cryogenian non-glacial interval support the emerging picture that Neoproterozoic oxygenation of the ocean was not monotonic; rather, at least one major interval of oxygenation following the Sturtian glaciation was followed by a return to widespread anoxia prior to the onset of the Marinoan glaciation. We hypothesize that this temporary oxygenation following the Sturtian Snowball Earth was linked to increased weathering and nutrient delivery, but this oxygen may have been consumed via remineralization of reduced carbon during the Taishir $\delta^{13} \mathrm{C}_{\text {carb }}$ excursion. This Cryogenian interval of oxygenation coincides with the earliest animal remains and the timing of the transition to bilaterian animals implied by molecular clocks, suggesting a link between oxygenation and the earliest evolution of animals. Subsequent return to anoxia may also help to explain the long fuse prior to the Cambrian explosion of marine animal diversity.

\section{Acknowledgements}

We thank Claire Miles, Karrie Weaver, Guangchao Li, Dave Mucciarone, Monique Foung, and Nicole O'Keefe for laboratory assistance; Erik Sperling, members of the Payne Paleobiology group, Thomas Bristow, David Johnston, and Uyanga Bold for helpful discussion; and Charlie Langmuir for preliminary elemental data. We gratefully acknowledge the constructive comments by Morten Andersen, Tais Dahl, and an anonymous reviewer that improved the manuscript. This research was supported by an American Chemical Society Petroleum Research Fund Grant (53241-ND2) to KM, NASA Astrobiology Institute (MIT node) support to FAM, and an Achievement Rewards for College Scientists (ARCS) Foundation Fellowship to KVL. The R code for our box model can be accessed at https://purl.stanford.edu/gx919xw2942.

\section{Appendix A. Supplementary material}

Supplementary material related to this article can be found online at http://dx.doi.org/10.1016/j.epsl.2016.10.043.

\section{References}

Andersen, M.B., Romaniello, S., Vance, D., Little, S.H., Herdman, R., Lyons, T.W., 2014. A modern framework for the interpretation of ${ }^{238} \mathrm{U} /{ }^{235} \mathrm{U}$ in studies of ancient ocean redox. Earth Planet. Sci. Lett. 400, 184-194.

Andersen, M.B., Vance, D., Morford, J.L., Bura-Nakić, E., Breitenbach, S.F.M., Och, L.M., 2016. Closing in on the marine ${ }^{238} \mathrm{U} /{ }^{235} \mathrm{U}$ budget. Chem. Geol. 420, 11-22.

Bachan, A., Kump, L.R., 2015. The rise of oxygen and siderite oxidation during the Lomagundi Event. Proc. Natl. Acad. Sci. 112, 4562-4567.

Banner, J.L., Hanson, G.N., 1990. Calculation of simultaneous isotopic and trace element variations during water-rock interaction with applications to carbonate diagenesis. Geochim. Cosmochim. Acta 54, 3123-3137.

Barnes, C.E., Cochran, J.K., 1990. Uranium removal in oceanic sediments and the oceanic U balance. Earth Planet. Sci. Lett. 97, 94-101.

Bjerrum, C.J., Canfield, D.E., 2011. Towards a quantitative understanding of the late Neoproterozoic carbon cycle. Proc. Natl. Acad. Sci. 108, 5542-5547.

Bold, U., Smith, E.F., Rooney, A.D., Bowring, S.A., Buchwaldt, R., Dudas, F.O., Ramezani, J., Crowley, J.L., Schrag, D.P., Macdonald, F.A., 2016. Neoproterozoic stratigraphy of the Zavkhan Terrane of Mongolia: the backbone for Cryogenian and early Ediacaran chemostratigraphic records. Am. J. Sci. 316, 1-63.

Brand, U., Veizer, J., 1980. Chemical diagenesis of a multicomponent carbonate system - 1: trace elements. J. Sediment. Petrol. 50, 1219-1236.

Brennecka, G.A., Herrmann, A.D., Algeo, T.J., Anbar, A.D., 2011. Rapid expansion of oceanic anoxia immediately before the end-Permian mass extinction. Proc. Natl. Acad. Sci. 108, 17631-17634. 
Bristow, T.F., Kennedy, M.J., 2008. Carbon isotope excursions and the oxidant budget of the Ediacaran atmosphere and ocean. Geology 36, 863.

Canfield, D.E., Poulton, S.W., Knoll, A.H., Narbonne, G.M., Ross, G., Goldberg, T., Strauss, H., 2008. Ferruginous conditions dominated later Neoproterozoic deepwater chemistry. Science 321, 949-952.

Chen, X., Romaniello, S.J., Hermann, A.D., Wasylenki, L.E., Anbar, A.D., 2016. Uranium isotope fractionation during coprecipitation with aragonite and calcite. Geochim. Cosmochim. Acta 188, 189-207.

Cohen, P.A., Macdonald, F.A., 2015. The Proterozoic record of eukaryotes. Paleobiology 41, 610-632.

Dahl, T.W., Boyle, R.A., Canfield, D.E., Connelly, J.N., Gill, B.C., Lenton, T.M., Bizzarro, M., 2014. Uranium isotopes distinguish two geochemically distinct stages during the later Cambrian SPICE event. Earth Planet. Sci. Lett. 401, 313-326.

Dunk, R., Mills, R., Jenkins, W., 2002. A reevaluation of the oceanic uranium budget for the Holocene. Chem. Geol. 190, 45-67.

Erwin, D.H., Laflamme, M., Tweedt, S.M., Sperling, E.A., Pisani, D., Peterson, K.J., 2011. The Cambrian Conundrum: early divergence and later ecological success in the early history of animals. Science 334, 1091-1097.

Feng, L.-J., Chu, X.-L., Huang, J., Zhang, Q.-R., Chang, H.-J., 2010. Reconstruction of paleo-redox conditions and early sulfur cycling during deposition of the Cryogenian Datangpo Formation in South China. Gondwana Res. 18, 632-637.

Fike, D.A., Grotzinger, J.P., Pratt, L.M., Summons, R.E., 2006. Oxidation of the Ediacaran ocean. Nature 444, 744-747.

Goto, K.T., Anbar, A.D., Gordon, G.W., Romaniello, S.J., Shimoda, G., Takaya, Y., Tokumaru, A., Nozaki, T., Suzuki, K., Machida, S., Hanyu, T., Usui, A., 2014. Uranium isotope systematics of ferromanganese crusts in the Pacific Ocean: implications for the marine ${ }^{238} U /{ }^{235} U$ isotope system. Geochim. Cosmochim. Acta 146, 43-58.

Henderson, G.M., Anderson, R.F., 2003. The U-series toolbox for paleoceanography. Rev. Mineral. Geochem. 52, 493-531.

Hinojosa, J.L., Stirling, C.H., Reid, M.R., Moy, C.M., Wilson, G.S., 2016. Trace metal cycling and ${ }^{238} \mathrm{U} /{ }^{235} \mathrm{U}$ in New Zealand's fjords: implications for reconstructing global paleoredox conditions in organic-rich sediments. Geochim. Cosmochim. Acta $179,89-109$.

Hoffman, P.F., Kaufman, A.J., Halverson, G.P., Schrag, D.P., 1998. A Neoproterozoic snowball earth. Science 281, 1342-1346.

Johnston, D.T., Macdonald, F.A., Gill, B.C., Hoffman, P.F., Schrag, D.P., 2012. Uncovering the Neoproterozoic carbon cycle. Nature 483, 320-323.

Kunzmann, M., Halverson, G.P., Scott, C., Minarik, W.G., Wing, B.A., 2015. Geochemistry of Neoproterozoic black shales from Svalbard: implications for oceanic redox conditions spanning Cryogenian glaciations. Chem. Geol. 417, 383-393.

Lau, K.V., Maher, K., Altiner, D., Kelley, B.M., Kump, L.R., Lehrmann, D.J., Silva-Tamayo, J.C., Weaver, K.L., Yu, M., Payne, J., 2016. Marine anoxia and delayed Earth system recovery after the end-Permian extinction. Proc. Natl. Acad. Sci. 113, 2360-2365.

Lenton, T.M., Boyle, R.A., Poulton, S.W., Shields-Zhou, G.A., Butterfield, N.J., 2014. Co-evolution of eukaryotes and ocean oxygenation in the Neoproterozoic era. Nat. Geosci. 7, 257-265.

Li, C., Love, G.D., Lyons, T.W., Scott, C.T., Feng, L., Huang, J., Chang, H., Zhang, Q., Chu, X., 2012. Evidence for a redox stratified Cryogenian marine basin, Datangpo Formation, South China. Earth Planet. Sci. Lett. 331-332, 246-256.

Ling, H.F., Chen, X., Li, D., Wang, D., Shields-Zhou, G.A., Zhu, M., 2013. Cerium anomaly variations in Ediacaran-earliest Cambrian carbonates from the Yangtze Gorges area, South China: implications for oxygenation of coeval shallow seawater. Precambrian Res. 225, 110-127.

Love, G.D., Grosjean, E., Stalvies, C., Fike, D.A., Grotzinger, J.P., Bradley, A.S., Kelly, A.E., Bhatia, M., Meredith, W., Snape, C.E., Bowring, S.A., Condon, D.J., Summons, R.E., 2009. Fossil steroids record the appearance of Demospongiae during the Cryogenian period. Nature 457, 718-721.

Lyons, T.W., Reinhard, C.T., Planavsky, N.J., 2014. The rise of oxygen in Earth's early ocean and atmosphere. Nature 506, 307-315.

Macdonald, F.A., Jones, D.S., Schrag, D.P., 2009. Stratigraphic and tectonic implications of a newly discovered glacial diamictite-cap carbonate couplet in southwestern Mongolia. Geology 37, 123-126.

Maloof, A.C., Rose, C.V., Beach, R., Samuels, B.M., Calmet, C.C., Erwin, D.H., Poirier, G.R., Yao, N., Simons, F.J., 2010. Possible animal-body fossils in pre-Marinoan limestones from South Australia. Nat. Geosci. 3, 653-659.
McManus, J., Berelson, W.M., Klinkhammer, G.P., Hammond, D.E., Holm, C., 2005. Authigenic uranium: relationship to oxygen penetration depth and organic carbon rain. Geochim. Cosmochim. Acta 69, 95-108.

Meece, D.E., Benninger, L.K., 1993. The coprecipitation of Pu and other radionuclides with $\mathrm{CaCO}_{3}$. Geochim. Cosmochim. Acta 57, 1447-1458.

Mills, D.B., Ward, L.M., Jones, C., Sweeten, B., Forth, M., Treusch, A.H., Canfield, D.E., 2014. Oxygen requirements of the earliest animals. Proc. Natl. Acad. Sci. 111, 4168-4172.

Morford, J.L., Emerson, S., 1999. The geochemistry of redox sensitive trace metals in sediments. Geochim. Cosmochim. Acta 63, 1735-1750.

Morford, J.L., Martin, W.R., Carney, C.M., 2009. Uranium diagenesis in sediments underlying bottom waters with high oxygen content. Geochim. Cosmochim. Acta 73, 2920-2937.

Noordmann, J., Weyer, S., Georg, R.B., Jöns, S., Sharma, M., 2015. ${ }^{238} \mathrm{U} /{ }^{235} \mathrm{U}$ isotope ratios of crustal material, rivers and products of hydrothermal alteration: new insights on the oceanic U isotope mass balance. Isot. Environ. Health Stud. 52, $141-163$.

Och, L.M., Shields-Zhou, G.A., 2012. The Neoproterozoic oxygenation event: environmental perturbations and biogeochemical cycling. Earth-Sci. Rev. 110, 26-57.

Romaniello, S.J., Herrmann, A.D., Anbar, A.D., 2013. Uranium concentrations and ${ }^{238} \mathrm{U} /{ }^{235} \mathrm{U}$ isotope ratios in modern carbonates from the Bahamas: assessing a novel paleoredox proxy. Chem. Geol. 362, 305-316.

Rooney, A.D., Strauss, J.V., Brandon, A.D., Macdonald, F.A., 2015. A Cryogenian chronology: two long-lasting synchronous Neoproterozoic glaciations. Geology 43, 459-462.

Rothman, D.H., Hayes, J.M., Summons, R.E., 2003. Dynamics of the Neoproterozoic carbon cycle. Proc. Natl. Acad. Sci. 100, 8124-8129.

Sahoo, S.K., Planavsky, N.J., Kendall, B., Wang, X., Shi, X., Scott, C., Anbar, A.D., Lyons, T.W., Jiang, G., 2012. Ocean oxygenation in the wake of the Marinoan glaciation. Nature 489, 546-549.

Schrag, D.P., Higgins, J.A., Macdonald, F.A., Johnston, D.T., 2013. Authigenic carbonate and the history of the global carbon cycle. Science 339, 540-543.

Shields, G.A., Brasier, M.D., Stille, P., Dorjnamjaa, D.-I., 2002. Factors contributing to high $\delta^{13} \mathrm{C}$ values in Cryogenian limestones of western Mongolia. Earth Planet. Sci. Lett. 196, 99-111.

Sperling, E.A., Wolock, C.J., Morgan, A.S., Gill, B.C., Kunzmann, M., Halverson, G.P., Macdonald, F.A., Knoll, A.H., Johnston, D.T., 2015. Statistical analysis of iron geochemical data suggests limited late Proterozoic oxygenation. Nature 523, 451-454.

Sperling, E.A., Carbone, C., Strauss, J.V., Johnston, D.T., Narbonne, G.M., Macdonald, F.A., 2016. Oxygen, facies, and secular controls on the appearance of Cryogenian and Ediacaran body and trace fossils in the Mackenzie Mountains of northwestern Canada. Geol. Soc. Am. Bull. 128, 558-575.

Stirling, C.H., Andersen, M.B., Potter, E.-K., Halliday, A.N., 2007. Low-temperature isotopic fractionation of uranium. Earth Planet. Sci. Lett. 264, 208-225.

Stirling, C.H., Andersen, M.B., Warthmann, R., Halliday, A.N., 2015. Isotope fractionation of ${ }^{238} \mathrm{U}$ and ${ }^{235} \mathrm{U}$ during biologically-mediated uranium reduction. Geochim. Cosmochim. Acta 163, 200-218.

Stylo, M., Neubert, N., Wang, Y., Monga, N., Romaniello, S.J., Weyer, S., BernierLatmani, R., 2015. Uranium isotopes fingerprint biotic reduction. Proc. Natl. Acad. Sci. 112, 5619-5624.

Tahata, M., Sawaki, Y., Yoshiya, K., Nishizawa, M., Komiya, T., Hirata, T., Yoshida, N., Maruyama, S., Windley, B.F., 2015. The marine environments encompassing the Neoproterozoic glaciations: evidence from $\mathrm{C}, \mathrm{Sr}$ and $\mathrm{Fe}$ isotope ratios in the Hecla Hoek Supergroup in Svalbard. Precambrian Res. 263, 19-42.

Tissot, F.L.H., Dauphas, N., 2015. Uranium isotopic compositions of the crust and ocean: age corrections, $\mathrm{U}$ budget and global extent of modern anoxia. Geochim. Cosmochim. Acta 167, 113-143.

Weyer, S., Anbar, A., Gerdes, A., Gordon, G., Algeo, T., Boyle, E., 2008. Natural fractionation of ${ }^{238} \mathrm{U} /{ }^{235} \mathrm{U}$. Geochim. Cosmochim. Acta 72, 345-359.

Zhang, F., Zhu, X., Yan, B., Kendall, B., Peng, X., Li, J., Algeo, T.J., Romaniello, S., 2015. Oxygenation of a Cryogenian ocean (Nanhua Basin, South China) revealed by pyrite Fe isotope compositions. Earth Planet. Sci. Lett. 429, 11-19. 